\title{
BUDDHISM AND PHENOMENOLOGY: WITH SPECIAL REFERENCE TO MINDFULNESS MEDITATION
}

\author{
PRADEEP P. GOKHALE \\ PhD, Adjunct Professor. \\ Savitribai Phule Pune University, Department of Pali. \\ 411007 Pune, India. \\ E-mail: pradeepgokhale53@gmail.com
}

Unlike most other philosophical systems of India, Buddhism, though it gives a central place to "consciousness" in its philosophical enquiry, does not raise its status to a transcendental metaphysical level. Buddhism, in this way, has a special affinity with the phenomenological approach. The present paper focuses on the points of a contact between phenomenology and Mindfulness meditation, the Buddhist spiritual practice. The paper is divided into three parts. The first part gives an account of the four kinds of Mindfulness meditation based on the Buddha's sermons on mindfulness. Then it focuses on their core features, namely, "objectivity", "impermanence and other essential features" and "dynamic, yet passive awareness". These features bring the two approaches close to each other. The second part brings out similarities and differences between the two approaches. The phenomenological approach, like the approach of Mindfulness meditation regards consciousness as being of the intentional and propositional nature. It also emphasizes immanent to consciousness and brackets transcendent to it. Both approaches exhibit a scientific temperament and both tend to be presupposition-less. In spite of these close similarities, there are glaring differences between these two approaches. The phenomenological inquiry is aimed at intellectuality, whereas that of the Buddhist approach is spiritual. Phenomenology attributes reality to essences, whereas there is a tendency to deny ontological status to essences in Buddhism. Husserl's acceptance of transcendental or pure ego contrasts with the no-self theory of Buddhism. Intentionality attributed to consciousness is also alien to all forms of Buddhism. The third part of the paper asserts the similarities and differences between the two approaches open to various possible forms of phenomenological practice. Furthermore, the paper suggests that different models of phenomenology are possible within Buddhism.

Key words: Mindfulness meditation, consciousness, svalakșaṇa, sāmānyalakșaṇa, emptiness, intentionality, essences, pure ego, presuppositionless approach, propositional consciousness, objectivity.

(C) PRADEEP P. GOKHALE, 2018 


\section{БУДДИЗМ И ФЕНОМЕНОЛОГИЯ: \\ СОПОСТАВЛЕНИЕ В КОНТЕКСТЕ МЕДИТАЦИИ ОСОЗНАННОСТИ}

\section{ПРАДИП П. ГОКХАЛЕ}

Доктор, адъюнкт-профессор.

Университет Савитрибай Фул Пуна, департамент Пали.

411007 Пуна, Индия.

E-mail: pradeepgokhale53@gmail.com

В отличие от других индийских философских систем, буддизм, хотя и отводит в рамках философского исследования центральное место понятию «сознание», он, тем не менее, не присваивает ему трансцендентально-метафизический статус. Буддизм в этом имеет сходство с феноменологическим подходом. В этой статье мы рассматриваем точки пересечения межу феноменологией и такой буддистской духовной практикой как медитация осознанности. Эта статья разделена на три части. В первой части рассматриваются четыре типа медитации осознанности, основанные на проповедях Будды об осознанности. Затем разбираются ключевые свойства этих типов медитации, а именно «объективность», «преходящесть и другие ключевые характеристики» и «динамическая и, вместе с тем, пассивная осознанность». Эти свойства сближают два рассматриваемых философских подхода. Во второй части на передних план выходят сходства двух философских подходов. Также как в рамках феноменологического подхода, медитация осознанности рассматривает сознание как имеющее интенциональный и пропозициональный характер. В рамках медитации осознанности также подчёркивается то, что имманентно сознанию и заключается в скобки трансцендентное. Оба подхода ориентируются на научный этос и тяготеют к беспредпосылочности. Несмотря на эти очевидные сходства, имеет место и явные различия между двумя философскими подходами. Цель феноменологического исследования - интеллектуальная, в то время как буддистский подход ориентируется на духовность. Феноменология приписывает реальность сущностям, в то время как в буддизме присутствует тенденция отрицать онтологический статус сущностей. Гуссерлевское принятие трансцендентального или чистого эго явно контрастирует с теорией не-я в буддизме. Также для всех форм буддизма нетипично приписывать сознанию интенциональность. В третьей части статьи утверждаются сходства и различия между двумя подходами, открытыми различным формам феноменологической практики. В статье также выдвигается предположение, что в рамках буддизма возможны различные модели феноменологии.

Ключевые слова: Медитация осознанности, сознание, svalakșaṇa, sāmānyalakșaṇa, пустота, интенциональность, сущности, чистое эго, беспредпосылочность, пропозициональное сознание, объективность.

\section{PRELIMINARIES}

For the Buddha, mind is the forerunner of all phenomena ('dhammas': that is, all that we accept, do, postulate and so on). And mind is the same as consciousness. Naturally consciousness - and it is not consciousness as a metaphysical entity, but 
consciousness as one comes across it - is supposed to regulate what can be accepted and what not in both empirical and moral realm. This leads the Buddha to set aside some of the transcendent-metaphysical issues which are not relevant to empirical-moral pursuit of the truths of life.

Though many other systems of Indian philosophy were concerned with consciousness as central to their philosophical inquiry, they had a tendency to raise the status of consciousness to transcendental metaphysical level, to regard it or associate it with an eternal substance such as Self (variously termed as ätman, brahman jīva and purușa $)^{1}$. Buddhism does not accept any such eternal conscious substance, but still gives a central place to 'consciousness' in its philosophical enquiry. This makes the Buddhist enquiry 'phenomenological'. In this sense, we could say that Buddhism, in comparison to most other philosophical systems of India, has a special affinity with Phenomenological approach ${ }^{2}$.

It has gone on record that Edmund Husserl had an occasion in 1924-25 to go through a large part of Karl Eugen Neumann's German translation of Suttapitaka and was very much impressed by that. In his remarks on the work he says:

What is probably the highest flower of Indian religiosity, a religiosity which looks purely inward in vision and deed - which, I should say, is not transcendent, but transcendental - enters the horizon of our religious and ethical as well as our philosophical consciousness only with these translations.... (Schuhmann, 1992, 25)

Here Husserl's description of the thought in Suttapitaka as 'not transcendent but transcendental' is important. Schuhmann $(1992,26-27)$ explains:

Buddhism, Husserl say's is not transcendent - not directed towards some deity who would dwell behind the world (as the Christian God is often believed to do) - but transcendental, that is, it looks inward and assigns to subjectivity the constitutive principles of reality. But there is more, as is already indicated by the fact that Husserl here takes over

1 Sānkhya and Yoga systems accept purușa as absolutely eternal and essentially conscious. Nyāya-Vaiśeșika system treats consciousness as a contingent quality of the eternal substance called àtman. Pūrva-mīmāmsā system accepts individual self as eternal and consciousness as its essence. Absolute non-dualist Vedānta (of Śankara) treats consciousness as the essence of Brahman and individual self as identical with it. Qualified non-dualist Vedānta (of Rāmānuja) and the Dualist Vedānta (of Madhva) accept the individual self as eternal, though not as identical with Brahman. Jainism too regards consciousness as the essence of the soul-substance which it regards as enduring eternally. It is only Lokāyata system which is in company with Buddhism in not accepting the eternal soul-substance. However, study of consciousness and its acts is not central to the methodology of Lokāyata as it is to that of Buddhism.

2 Though there are some ideas in Buddhism suggesting eternality (for example, nirvāna as 'asamiskrta-dharma'), their status as the evidences of Buddhist eternalism is dubious. 
and makes his own the Kantian distinction between transzentent and transzendental. Transcendentality is indeed one of the more noble predicates Husserl usually reserves for his own phenomenology. The fact that he is here ready to share it with Buddhism amounts to nothing less than putting Buddhism and phenomenology on a par.

One could add here that unlike Buddhism the systems like Vedānta, Sānkhya and Nyāya-Vaiśeșika can be called 'transcendent' rather than 'transcendental' '. I want to suggest here that the scholars of Indian philosophy, who were also interested in phenomenology have generally overlooked this fact.

In the last century the mainstream Indian philosophy was presented before the west as represented first by Vedānta, and then by Nyāya. Hence there were attempts to bring these systems close to the dominant trends in western philosophy. J. N. Mohanty (1962), who is a phenomenologist and also a Naiyāyika, tried to explain Nyāya epistemology in phenomenological terms. The scholars like R. Balasubramanian (1992), a staunch advocate of Advaita Vedānta, tried to give a phenomenological explanation of Advaita Vedānta. Similarly, D. P. Burte (2015) attempted to interpret Sānkhya and R. Sinari (1965) and R. Puligandla (1970) have tried to interpret Yoga in terms of Husserl's Phenomenology.

It is not true that the phenomenological potential of Buddhism was not explored. Recently the scholars like Thomas Kochumuttom (1982) and Dan Lusthaus (2006) have tried to interpret Yogācāra Buddhism as the Buddhist Phenomenology. For that they tried to deny the commonly accepted idealistic interpretation of Yogācāra Buddhism, which is rather difficult to do. On the other hand, Pali Buddhism, is not even allegedly idealistic. Though it can be regarded as realist in so far as the existence of rupaskandha (matter) is concerned, it elucidates matter not as it exists in itself, but in the form in which it is presented to consciousness. Hence it seems possible to explore the phenomenological potential of Pali Buddhism without going for its radically new interpretation.

\section{AGENDA OF THIS PAPER}

In this paper I will try to explore the phenomenological potential of Mindfulness meditation with a core-aspect of Pali Buddhism.

The paper is divided into three parts. In the first part I will give a brief account of Mindfulness meditation focusing on its core features. In the second part I will bring out similarities and differences of Mindfulness-meditational approach with the Hus-

3 See foot-note No. 1 above. 
serlian phenomenology. In view of the close similarity and glaring differences between the two approaches I will claim in the third part that if we do not follow a rigid concept of phenomenology and allow phenomenology to be done in various ways then we can make room for Buddhist Phenomenology, though probably it would be of some other type than that of Husserl. I will further suggest that within Buddhism different models of phenomenology are possible.

\section{PART I: WHAT IS MINDFULNESS MEDITATION?}

We are traditionally told that the Buddha gave us two kinds of meditations: concentration mediation (samathabhāvanā) and insight-meditation (vipssanābhāvanā). In concentration mediation one-pointed-ness of mind is the core factor. In insightmeditation, on the other hand one develops a direct insight into the three characteristics of all conditioned objects. Buddhist tradition claims it to be a direct way to the realization of Nibbāna.

'Vipassana', which is understood as the direct insight into the true nature of things is not found mentioned as a distinct kind of meditation in early Buddhist suttas. 'Vipassana $\vec{a}$ in this sense cannot be called a meditation proper. However, it can be considered as a goal of meditative practice. 'Vipassana ' can be understood as pañ $\tilde{a} \bar{a}$ (Sanskrit: prajū $\bar{a}$; insight or wisdom) resulting from a certain meditative practice.

The point can be explained in terms of the threefold classification of wisdom: textual/scriptural (sutamayā), rational (cintāmayā) and meditational (bhāvanāmayā). The idea is that what one understands from teachers at the level of scriptural wisdom, one examines rationally at the second level, and meditates on it and understands it directly at the level of meditational wisdom. Meditational wisdom in this way can be regarded as the goal of meditation.

The question naturally arises as to which kind of meditation is appropriate for this goal. The natural answer, I suppose is that it is the meditation designated by 'right mindfulness' (sammā sati) as a limb in the 'noble eightfold path' or the one, which can be called the practice of mindfulness meditation. For instance Vasubandhu says in Abhidharmakośa-bhāşya, "The one who has accomplished concentration meditation (śamatha), should practice mindfulness meditation (smrtyupasthāna-bhāvanā) for the sake of achieving meditational insight into truth (vipaśyanā)" (Pradhan, 1967, vi.14ab; Nanamoli, 2010).

The term used for 'mindfulness' in the Buddhist theory of meditation is 'sati' (smrti in Sanskrit) also means recollection. In fact mindfulness is similar to recollection insofar as it is an awareness of something which has already happened in past. 
But mindfulness is not awareness of something happened in remote past, but of something that has happened in immediate past which is presented to our consciousness almost as something present.

The situation is like this. Something happens in my life world, and I become immediately aware that such and such thing 'is happening' (though actually it 'has happened' one moment back). Hence there is a mindful awareness of 'something', which immediately follows 'that thing'.

The word used for this kind of meditation in the sermons on Mindfulness ${ }^{4}$ is anupassanā. Literally anupassanā means 'succeeding perception', that is, seeing/ observing/ becoming aware of something, immediately after that something is presented before consciousness ${ }^{5}$.

As it is well-known, the Buddha in the sermons on mindfulness classified mindfulness into four kinds:

1) Mindfulness of bodily objects (kāyagatā sati)

2) Mindfulness of sensations (vedanānupassanā)

3) Mindfulness of mind (cittānupassanā)

4) Mindfulness of doctrinal factors (dhammānupassanā)

(1) Mindfulness of bodily objects (kāyagatā sati)

The following meditative practices are included under this heading:

1) One vigilantly observes in-breathing and out-breathing as they happen from moment to moment.

2) One is aware of various bodily activities while performing them.

3) One internally observes one's body part by part and notices its loathsomeness.

4) One observes dead bodies in different conditions.

\section{(2) Mindfulness of sensations (vedanānupassanā)}

According to the meditative practice included under this heading, one observes different parts of the body internally and checks the kinds of feelings or sensations one experiences there. The sensation may be pleasant, unpleasant or neutral. Again it may

4 The major suttas on this theme are Satiptțānasutta (Majjhimanikāya) and Mahāsatipațthānasutta (Dìghanikāya).

5 I have suggested that the concepts of mindfulness (sati) and succeeding perception (anupassanā) belong to the same epistemic category. However, both of them should be distinguished from the concept of anusssai (anusmrti in Sanskrit) used in the works such as Abhidhammatthasamgaho and Visuddhimaggo, which means reflection or contemplation rather than mindfulness. 
be gross or subtle, worldly or unworldly (sāmișa or nirāmișa). One has to observe how the sensation arises and passes away. One is not supposed to develop love or hatred towards a sensation even if it be pleasant or unpleasant.

\section{(3) Mindfulness of mind (cittānupassanā)}

Our mind, like other things, undergoes transformations. At times it may be concentrated, at times it may be disturbed, it may be having desire, aversion or delusion, it may be happy or unhappy, free or bound. One has to be aware of the state of mind, that is, the state of consciousness, at any point of time vigilantly and also see how it arises and passes away. This is the essence of this type of meditative practice.

A question can arise regarding the working of mind in in the mindfulness of mind. How is mindfulness about mind or about a mental state possible? The mindfulness about mind seems to imply the duality of minds: The mind (that is, cognition) which is aware and the mind (that is, cognition) or mental state of which it is aware.

For explaining this kind of situation at least four models are available in Indian philosophy.

1) Succeeding Cognition Model: If cognition or a mental state occurs at one moment, we can be directly aware of it at the next moment. This is the Nyāya position. Naiyāyikas call this second awareness as 'succeeding determination' (anuvyavasāya). The Buddhist notion of 'succeeding perception' (anupassanā) seems to have the same connotation though the metaphysical description of the situation would be different ${ }^{6}$.

2) Dualistic Model: Awareness of cognition becomes possible when the matter and the conscious soul meet. This the Sānkhhya model also accepted by Patañjali's Yoga. Accordingly the cognitive faculty (buddhi) is material. It assumes the form of an object and presents itself before the conscious soul. The soul becomes aware of the object as represented by the cognitive faculty.

3) Inferential Model: A direct cognition is always object-oriented and never cognition-oriented. The cognition of a cognition can only be indirect. Such an indirect cognition of a cognition can be based on inference or postulation. This was the position of the Bhātța school of Mīmāmsā.

4) Self-illumination Model: Cognition is self-illuminating. Cognition of cognition occurs at the same time when one has the cognition of an object. This self-illuminating cognition is called svasamvedana. This is the Buddhist position, particularly that of Dinnnāga, Dharmakīrti and their followers of Sautrāntika and Yogācāra schools.

6 For Naiyāyikas every occurring consciousness is a transitory quality of a soul-substance. Buddhists accept a series of transitory consciousnesses without positing a soul-substance. 
This was also the position of the Prābhākara school of Mīmāmsā and of some Vedānta schools.

The question about mindfulness of mind is, whether it follows the model of 'succeeding awareness', (anuvyavasāya or anupassanā) or that of self-illuminating cognition (svasamvedana). Buddhists are generally inclined to self-illumination model because they say that mind and mental state are inseparable. There cannot be pleasure without pleasure-awareness, though there can be table-awareness without a real table. This position is similar to Husserl's position that in the case of consciousness of an external object the actual object is transcendent whereas in the consciousness of a mental state, the actual mental state is necessarily immanent (Husserl, 1983, 78-80).

But self-illumination model has a difficulty when we are particularly talking about mindfulness meditation. For example we have to distinguish between being angry and being aware of one's own anger. If we are not mindful enough, we may be angry, but not 'aware' that we are angry. In fact mindfulness of mind specifically prescribes that. If anger arises in my mind, immediately, which means at the very next moment, I should be aware that an angry mind has arisen.

Perhaps the discrepancy can be solved by distinguishing between awareness in general and the mindful awareness. According to self-illumination model, if any mental state arises in me, I am simultaneously aware, however faintly, of the mental state. This could be understood as pre-reflective self-awareness. But pre-reflective self-awareness may not be mindful awareness. The practitioner of mindfulness meditation may be mindfully aware of the mental state at the next moment (or sometimes at the same moment). It could be a kind of reflective awareness.

(4) Mindfulness of doctrinal factors (dhammānupassanā)

A question can be asked about the meaning of the term dhamma in dhammānupassanā. I have argued elsewhere (Gokhale, 2007) that the word dhamma in the term dhammānupassanā does not mean phenomena or things in general or objects of mind, but 'doctrine' or doctrinal factor. Dhammas in this context stand for the doctrinal factors such as hindrances (nivvarana), aggregates (khanda) and four noble truths (ariya-saccāni). The practice of dhammānupassanā really means developing awareness of doctrinal factors as they are exemplified by our day-to-day experiences. 


\section{CORE FEATURES OF MINDFULNESS MEDITATION}

Broadly speaking there are three core features, which are shared by most of the types and sub-types of mindfulness meditation. They are (i) Objectivity, (ii) Realization of impermanence and other common characteristics and (iii) Dynamic, yet passive awareness. Let us consider them one by one.

(i) Objectivity

One of the important features of mindfulness meditation is that there is an emphasis on observing various aspects of one's own nature and other things objectively and on avoiding subjective elements such as attachment, clinging, lust and grief. In other words, there is an emphasis on 'seeing the things as they are'. Just to cite one specimen, "A disciple while walking understands - 'I am walking', while standing, understands, 'I am standing...." (Narada, 1988, 704)

This reminds us of Tarski's $(1944,343)$ well-known example of the material adequacy condition of any theory of truth: 'Snow is white' is true if and only if snow is white. Tarski's theory was a development over Aristotle's version of the correspondence theory of truth ${ }^{7}$. This condition applies well to mindful awareness. To stretch the simile the Buddha is expecting us here that our mindful awareness should correspond exactly with the way the things are. In other words, he is applying the correspondence theory of truth, which is primarily epistemological, for moral-soteriological purpose.

In the case of mindfulness meditation 'the thing as it is' can be understood as the own nature or the unique characteristic (svabhāva or svalakșana) of the phenomenon under consideration. Vasubandhu, while describing mindfulness meditation, says, "One examines body, sensation, mind as well as doctrinal factors in terms of their unique characteristics and general characteristics (svalakșaṇa and sāmānyalakșaṇa)" (Ñanamoli, 2010, vi.14).

Here a unique characteristic of a phenomenon is its own nature (svabhāva).

(ii) Impermanence and other characteristics

The second important feature of mindfulness meditation is that there is an emphasis in it on changing nature of phenomena. This is seen in on all the four kinds of mindfulnesses.

1) In mindfulness of body one is aware of various bodily states and functions as they occur and change.

2) In mindfulness of sensations one is aware of pleasant, painful and neutral sensations as they arise and pass away.

7 "To say that that which is, is not, and that which is not, is, is a falsehood; while, to say that which is, is, and that which is not, is not, is true", Metaphysics by Aristotle (1011b26) quoted by Tarski $(1944,343)$. 
3) In mindfulness of mind one is aware of various mental states as they arise and pass away.

4) Similarly in the mindfulness of doctrinal factors, particularly those like hindrances (nivarana) and aggregates (skandha), one is aware of the factors as they arise and pass away in one's psychic life.

Thus one is directly aware of impermanence of phenomena in various forms of mindfulness meditation. The awareness of impermanence (anityatā) has also implications to the other two characteristics of the respective objects of meditation, viz. soul-less-ness (anātmatā) and unsatisfactoriness (duhkhatā). It may be noted here that the doctrine of three characteristics (trilakșaṇa) is central to early Buddhist theory of reality and vipassana also incorporates the insight into the three characteristics.

The three characteristics are interconnected. In Anattalakkhanasutta the Buddha shows how soul-less (anattā) nature of the conditioned objects is the root of impermanence. Similarly unpleasantness is inferred from impermanence (which is directly known) and the soul-less nature (anattā) is derived from both, i.e. impermanence and unpleasantness.

In Sarvāstivāda literature the fourth characteristic namely 'emptiness' (śūnyatā) is added to the list of three. For instance we have seen Vasubandhu's statement that in mindfulness meditation one examines phenomena in terms of their unique characteristics and general characteristics (svalakșana and sāmänyalakșana). Now under general characteristics he includes emptiness (śūnyatā) in this way: “...impermanence (anityatā) of the composite objects, unsatisfactoriness (duhkhatā) of the defiled objects, and empty and soulless nature (śūnyatā and anātmatā) of all things" (Ñanamoli, 2010, vi.14).

It should be noted here, however, that this 'emptiness' is not to be equated with the 'emptiness' accepted by the Mādhyamika school. In fact meaning of the term śunyatā is an important problem in Buddhist philosophy. In Theravāda as well as Sarvāstivāda it is to be taken as an offshoot of anityatā and anātmatā. In Mind-only ( cittamātratā) school it refers to unreality of the external world. In Mādhyamika Buddhism it stands for essencelessness (nihsvabhāvatā) of all phenomena.

These diverse meanings of śunyatā are relevant for phenomenological interpretation of Buddhism. That is because for realist schools of Buddhism śünyatā is the common 'essence' (sāmānyalakșṇa) of all phenomena, whereas for Mādhyamikas it indicates that things have no essences at all.

(iii) Dynamic, yet passive awareness

The third feature of mindfulness meditation is almost a corollary of its two features namely objectivity and focus on impermanence. It is that the consciousness, 
which operates in mindfulness meditation, is dynamic, yet passive. This appears to be paradoxical but the paradox can be resolved in the following way.

As we have seen, the consciousness in mindfulness meditation takes note of phenomena as they are. But the expression 'as they are' does not refer to anything static. It refers to things that happen, occur, that is, arise and pass away. Again consciousness, which takes note of the changing phenomena, is not itself constant but it changes with the object. Hence mindful consciousness is existentially dynamic.

We have also seen that the mindful consciousness does not construct or create the object, but simply receives it as it is given, or 'describes' it without distorting it. Generally creation or construction or distortion of an object is caused by passions or attachment. Mindful awareness on the other hand is detached, dispassionate awareness. It is passive in moral-psychological sense.

\section{SVALAKȘANA AND SĀMĀNYALAKȘANA ACCORDING TO DHARMAKİRTI}

Though the terms svalakșaṇa and sāmānyalakșaña, which are central terms of Buddhist ontology, were originally used in Sarvāstivāda ontology, they were used with a different sense from the meaning they assumed in Dharmakirti's epistemology. According to Sarvāstivāda ontology svalakșaṇa means own character (svabhāva) of a thing ${ }^{8}$. As against this svalakșaṇa according to Dharmakīrti means unique particular or self-characterized particular'.

An offshoot of the above distinction is that svalakșaṇa as understood by Sarvāstivāda school of Buddhism can be expressed by a judgment, whereas svalakșana of Dharmakìrti cannot be so expressed. Dharmakìrti calls unique particular the ultimate reality and regards it as the object of immediate awareness which is non-judgmental or non-propositional. He distinguishes this awareness, which he calls direct awareness (pratyakșa-pramāna), from the judgmental awareness or mental construction (vikalpa) which immediately follows the direct awareness. In terms of this distinction we can say that a mindful meditative awareness is not direct awareness (pratyakșapramāna) as accepted by Dharmakīti, it is a judgmental awareness (savikalpa-jñāna), or a cognition which determines or understands adequately what is given in direct awareness.

8 Grammatically it will be derived as karmadhāraya ('svam lakșaṇam') or tatpuruṣa compound ('svasya lakșaṇam').

9 Grammatically it will be derived as a bahuvrīhi compound ('svaṁ lakșaṇam yasya tat'). 
This does not mean that this mindful awareness must have an explicit propositional form. However, it can be understood as a thought, a mental picture one draws for oneself, which is expressible by a proposition.

\section{MINDFULNESS MEDITATION AND 'VALUES'}

If we concentrate on the core aspect of Mindfulness meditation, we can say that the cognition contained in it is descriptive and it does not have evaluative content. For example while observing bodily movements one has to treat all types of movements alike. No movement is special or more important than another. While experiencing and judging sensations, all sensations are to be treated as of equal value: whether a sensation is pleasant or painful or neutral, whether it is gross or subtle.

This attitude of mindfulness meditator seems to follow Wittgenstein's picture theory of proposition. According to this theory a true proposition or a thought depicts a fact truly; it does not go beyond that. Rather, it cannot say anything 'higher'10, it does not and cannot attach any value to the fact. And this is important for mindfulness meditation also. The common message of Wittgenstein's picture theory and the Buddha's mindfulness meditation seems to be: "If we look around the world as it is, then we do not find 'values' (which are nothing but the projections of our subjective attitudes) anywhere in it".

Paradoxically enough, this attitude of not attaching importance to facts is itself an 'important' attitude for Buddhism, because through the development of this attitude one reduces one's attachment towards the world. The Buddha as a moral psychologist was aware of this value of developing value neutral approach to reality. Wittgenstein's picture theory does not have this implication.

Of course the core features of mindfulness meditation I have described are not common to all the meditative practices included in Satipatthanna-sutta. Some are value-loaded (for example, awareness of hindrances and enlightenment-factors in dhammānupassanā), some involve imagination and go beyond pure objectivity (for example observing dead bodies in kāyagatā sati). I am not focusing on these features, which I call non-core features for the present purpose.

10 Compare Wittgenstein's (1922) propositions in Tractatus: "All propositions are of equal value" (6.4); "The sense of the world must lie outside the world. In the world everything is as it is and happens as it does happen. In it there is no value- and if there were, it would be of no value"(6.41); "....Propositions cannot express anything higher" (6.42). 


\section{PART II: COMPARISON BETWEEN THE TWO APPROACHES}

The value neutral descriptive approach which is a core feature of a mindfulness meditation, is closely comparable with phenomenological approach of Husserl's phenomenology. There are important similarities and differences between the two approaches to which we will turn now.

IIa: Similarities between the two approaches

(1) Intentionality

Both are exercises with consciousness and concerned with what is immediately given in consciousness.

Husserl insists that consciousness is essentially intensional. It is always consciousness of something. In mindfulness meditation too one exercises mindful consciousness as consciousness of something- be it a bodily state or process, a sensation, a state of mind itself or a doctrinal factor as exemplified in experience. There is no reference to consciousness without object anywhere in the description of mindfulness meditation.

(2) Propositional nature of consciousness

The nature of consciousness with which both the approaches are concerned, is judgmental or propositional. It is expressible in language. Though there may be difficulties in expressing the experience in clear and distinct terms it is not something which cannot be expressed at all. In this sense the experience in both is not ineffable or mystical.

(3) Bracketing what is beyond consciousness

The existence of what is beyond consciousness is bracketed in both. Mindfulness meditation as discussed in the suttas like Satipațthannasutta occurs as a part of Theravāda Buddhism and the Theravāda Buddhism is realistic in its world view. However, although the existence of the external world is accepted as a background, it is bracketed in most of the practices of mindfulness-meditation.

(4) Immanent versus transcendent

In both the approaches we are not primarily interested in the nature of the world as it may be accepted or believed to be there. But we are interested in the objects or phenomena as they are directly given to consciousness.

Here the distinction between what is immanent and what is transcendent to consciousness becomes important. Both phenomenology and mindfulness-approach attach importance to what is given as immanent. What is transcendent to consciousness is not denied but set aside or put into a bracket.

(5) Bracketing soul, God and transcendental metaphysics

Here bracketing is distinguished from denying and doubting. Hence the practitioner of Mindfulness meditation may not accept or deny or doubt the existence of 
God, soul or life after death. But he is supposed to bracket these ideas while practicing meditation.

It is interesting to note that Mr. S. N. Goenka, the founder of Vipassanā International Academy, in his Vipassana meditation course often asked the meditators to suspend the belief in God or Ätman and not to accept or deny or doubt their existence.

This is in tune with the spirit of bracketing the existence of the world and other transcendent objects in phenomenology.

(6) 'Scientific temperament'

Both the approaches exhibit 'scientific temperament' (in a broad sense) of their respective authors. It is through this scientific approach that they try to have direct access to reality.

The expression 'to the things' („Zu den Sachen“) suggests this. The corresponding expression in Buddhism is 'seeing the things as they are' (yathäbhütavastudarśana).

It is significant here to note that the Late Vipassanā Master Satyanarayan Goenka ${ }^{11}$, whose interpretation of the Buddha's message is based on Satipatțannasutta, describes the Buddha as a scientist, neither a religious leader nor a speculative philosopher ${ }^{12}$.

(7) Presupposition-less approach

In Kesaputtiyasutta of the Añguttaranikāya (popularly known as Kālāma-sutta) the Buddha asks Kālāmas not to go by hearsay, rumours, tradition, scriptures, supposition, speculative reasoning, appearances, notions or by personal authority but to accept or reject a view on the basis of one's own experience (Narada, 1988, 284-285). The Buddha's appeal to people was to 'come and see' (ehi-passiko), to examine, explore and then accept or reject. This approach of the Buddha was behind his theory of meditation also. It was a presupposition-less approach which is supposed to be a core feature of phenomenological inquiry also.

In spite of these close similarities; mindfulness meditational approach differs from phenomenology in some fundamental respects.

IIb: Differences

(1) Difference in goals

One important difference is as follows. Though both the approaches exhibit scientific temper as suggested above, the goals of the two inquiries are different. The

11 For example, in an interview published in Tricycle (Goenka \& Twokov, 2000), he says: "When I began to learn Vipassana meditation, I became convinced that Buddha was not a founder of a religion, he was a super-scientist. A spiritual super-scientist".

12 The difference between the scientific temperaments of the Phenomenologist and the Buddhist would be that the former would give primacy to eidetic sciences as against the empirical sciences whereas the latter would give it to empirical sciences. 
goal of mindfulness-meditational approach is spiritual emancipation, i.e., realization of nibbanna, whereas the goal of the phenomenological inquiry is creation of a philosophy which has the status of rigorous science.

The difference between the goals of the two inquiries could be articulated as follows: The final goal of a Buddhist is not essentially intellectual whereas that of phenomenology is. A phenomenologist would aim at and probably stop at an intellectual insight into the essences. For Buddhist meditators the intellectual wisdom (cintāmaya pañ $\tilde{a})$ can be an intermediate goal, but it cannot be the final goal. It is a step towards the final goal, which is the wisdom (insight) based on meditation (bhāvanāmayā pañ $\tilde{n} \bar{a})$.

(2) The role that 'essences' play

Another important difference is about the role that 'essences' play in the two approaches.

Though prima facie anything that appears in consciousness can be called a phenomenon, the phenomena in technical sense according to the phenomenological approach are the essences. Essences are those which make the objects what they are. The essences are grasped through intuition and phenomenology is a reflective exercise to investigate into these essences. In mindfulness meditation, on the other hand, one deals with empirical phenomena directly given to one's senses or to one's mind. While doing so, one does not bracket their existence or factuality, though one brackets their apparently substantial or enduring character. We have seen that a mindfulness meditator investigates into empirical phenomena in terms of their uncommon and common characteristics or essences (svalakșṇa and sāmānyalakșaṇa). But a mindfulness meditator does not concentrate on these essences for their own sake. The essences for the meditator are only the tools of understanding the empirical and psychical reality.

(3) The ontological status of essences

The ontological status of essences can be a major differentiating point between the two approaches. Husserl seems to believe that the essences are real and they can be directly grasped by consciousness through intuition.

Buddhists are not unanimous on the status of essences. In Theravāda and Sarvāstivāda, it seems, the essences are not challenged, but they are given instrumental value to understand the reality, which is transitory. In Sautrāntika and Yogācāra and also in Mādhyamika, there is a tendency to deny the ontological status to essences.

For Dharmakīrti, for instance, essences have a logico-linguistic status, but no ontological status. They are conventionally real (sam $v r t i-s a t)$ and not ultimately real (paramārtha-sat). 
So if this position, which denies any ontological status to essences, forms the basis of a 'phenomenological' enquiry, it will lead to a phenomenology different from Husserl's phenomenology.

(4) The status of ego

Another differentiating point is the status of ego. Husserl in Ideas goes on excluding various objects of belief, by using the method of reduction (epoche). He distinguishes between empirical ego and transcendental ego, which he also calls pure ego. Empirical ego according to him is a constituted ego and it is not real. Here his view is compatible with the Buddhist no-self doctrine.

But he refuses to exclude pure ego, or transcendental ego which according to him is behind any act of consciousness (Husserl, 1983, 132-133).

It is interesting to note here that in his earlier work, Logical Investigations, Husserl had advocated skepticism with respect to the question about the pure ego (Husserl, 1983, 133, fn. 10). The concept of phenomenological ego he introduced there meant an interconnected unity of experiences; his approach resembles David Hume's approach (Balslev, 1992, 134) and consequently the Buddhist approach to self, which reduces self either to consciousness series or to five aggregates.

But the concept of transcendental ego or pure ego which he forms in Ideas is not compatible with the Buddhist approach.

(5) The question of intentionality

There is one more issue and it is the intentionality of consciousness. According to Husserl consciousness is intentional and it is essentially so or necessarily so. As I have indicated before, in the exercise of mindfulness meditation one is always conscious of something. Hence the two approaches match to a certain extent. But the intentionality of consciousness is not unanimously accepted as the necessary aspect of consciousness in different schools of Buddhism.

As I have pointed out before, Pali Buddhism acknowledges two kinds of meditation: Concentration meditation and insight meditation ${ }^{13}$. Concentration meditation is further classified into two kinds: concentration on the object having a form (rüpadhyāna) and concentration on a formless object (arūpadhyāna). The so-called formless objects acknowledged in Buddhism are 'infinite space, 'infinite consciousness', 'nothingness' (äkiñcanyāyatana) and 'neither perception nor non-perception'. It is very much doubtful whether in the so-called formless meditative states, one is conscious of something. These formless meditations are supposed to culminate into

13 Mindfulness meditation with which we are primarily concerned with in this paper belongs to the category of insight meditation. I have suggested that in this type of meditation intensionality condition is satisfied. 
a state in which these is no perception, no sensation (samjñ $\bar{a}$-vadayita-nirodha). This state of consciousness is supposed to be definitely without an object. This questions intensionality as an essential character of consciousness.

In Mind-only school of Buddhism, it is claimed that the subject-object duality that we find in consciousness is illusory and finally consciousness should be free from it. Naturally such a freed consciousness will cease to be intensional.

Now the question is, if intensionality is not accepted as an essential feature of consciousness, does it challenge the very foundation of phenomenology? I suppose that it can set limits to phenomenological inquiry, but cannot make it impossible.

(6) The question of phenomenology as a presupposition-less inquiry

At a more general level we can raise a question about the nature of phenomenology as a presupposition-less inquiry. A phenomenological exercise is intended to be free from presuppositions. It is possible, however, that a phenomenologist while developing such a presupposition-less approach might invite or allow certain presuppositions, consciously or unconsciously.

Hence, the existence of essences, existence of pure ego and intensionality of consciousness may be regarded as the presuppositions of Husserl's phenomenology, which for Husserl were not presuppositions but something essential to the correct understanding of consciousness.

\section{PART III: POSSIBILITY OF DIFFERENT PHENOMENOLOGICAL MODELS WITHIN BUDDHISM}

Now again the question is, suppose someone does not entertain the above presuppositions and yet focuses on consciousness and on what is given to consciousness, then will it be called phenomenology or not? I propose to claim that it can be. This leads to the possibility of a variety or varieties of phenomenology other than that of Husserl.

Arguably Buddhism carries most minimum presuppositions as compared to most of the other schools of Indian philosophy. But within Buddhism we can arrange different schools in terms of degrees of their ontological commitments. In other words we can have 'degrees of presupposition-less-ness' within Buddhism which can give rise to different models of phenomenology. Mind, which is the same as consciousness, is central to all the schools. But what is given to this consciousness and how it is given; similarly what is not given but only constructed differs from school to school.

In Theravāda and Sarvāstivāda, essences play a more constructive role. In Sautrāntika and Yogācāra there is a tendency to regard essences as mental constructs and 
to give them more and more negative role. They do this by developing the doctrine of exclusion (apoha). As against this Mādhyamika School questions all essences which it does by using reduction-ad-absurdum method (technically called as prasanga method). This diversity gives rise to the possibility of different phenomenological models within Buddhism. Even within a single school of Buddhism, we have to distinguish between the ordinary state of consciousness and the enhanced or purified state of consciousness. A phenomenological model which is applicable to the former will no longer be applicable to the latter.

For example, in Theravāda and Sarvāstivāda, consciousness is understood not as a uniform unit but a complex whole. It contains many factors- factors common to all minds (sarva-citta-sādhāraṇa) such as contact (sparśa), recognition (sañjñ̄a), volition (cetanā) and thought (mati) (Pradhan, 1967; Ñanamoli, 2010, 2.24). Accordingly all consciousness has sensory, connative and conceptual-intellectual aspects in one. But when we consider the same mind in the state of formless meditation or in the state of realisation of cessation (nirodha-samäpatti) it loses its complex character and hence the general phenomenological model will not be operative in understanding of those enhanced states of mind.

Unlike in Theravāda or Sarvāstivāda, 'consciousness' in Sautrāntika and Yogācāra schools tends to be understood as more atomistic and simple. Particularly perceptual cognition is defined as non-judgmental (nirvikalpaka). Hence these schools are more difficult to be captured in terms of Husserl's phenomenology.

\section{Closeness to Merleau Ponty's phenomenology?}

We have seen that consciousness involved in mindfulness-meditation is judgmental or propositional. Moreover, it is essentially embodied consciousness. It could be argued that mindfulness-meditational approach is closer to Merleau Ponty's phenomenology than to that of Husserl. However, the similarity between them cannot be stretched too far. Here the question is how we can make sense of mindfulness of body (kâyagatā sati) in Merleau Ponty's framework. That is because mindfulness of body involves developing an objective awareness of body and parts and activities of the body. Merleau Ponty's phenomenology of body does not make room for such an 'objective awareness'. As Fréeacute de Vignemont (2015) observes, Merleau-Ponty draws the distinction between the objective body made of muscles, bones and nerves and the lived body, that is, the body that we experience in pre-reflective awareness. He argues that the lived body is not an object that can be perceived from various perspectives, left aside or localized in objective space. It cannot even be represented because, on his 
view, representing the body necessarily involves adopting an objective stance on the lived body. The objectified body could then no longer anchor the way we perceive the world.

As against this, observing the body internally, part by part, dissecting it mentally is an important part of developing mindfulness of body according to Buddhism. In this exercise body is to be understood as a combination of elements ('sanghāta') and not as a composite whole ('avayavin') which has its identity over and above the elements. This and other exercises of the mindfulness of body are aimed at freedom from our clinging to the body, removing the sense of 'I and mine' associated with the body.

Contrariwise, Merleau Ponty seems to look at body as a composite whole (which exists over and above its parts). This could be because his aim is not to transcend the embodied-ness of our being but to accept it and to understand it as given.

Acknowledgements: I introduced some core ideas of this paper in a paper presented in the International Conference on "Buddhism: Dhamma and Abhidhamma" organized by Somaiya Centre for Buddhist Studies, Mumbai, on 5-7 March, 2006 (subsequently published in the proceedings of the conference). I presented a substantially revised version of the paper in the International Conference on Buddhism and Phenomenology jointly organized by Institute of Philosophy (Russian Academy of Sciences) and Tibetan Culture and Information Center in Moscow, on 7-8 November, 2016, and then in the Workshop on "Phenomenology and Care", Organized by the Department of Philosophy, University of Mumbai on 3-9 March 2017. The present paper is a further revision of that. I thank Deepti Gangavane, Kanchana Mahadevan, Mahesh Deokar, Daniel Stuart, and Mohit Tandon for their comments on the earlier versions of the paper. I am grateful to Victoria Lysenko and Kanchana Mahadevan for inspiring me to revise my earlier paper at its different stages.

\section{REFERENCES}

Pradhan, P.(Ed.). (1967). Abhidharmakośa and Abhidharmakośabhāṣya of Vasubandhu. Patna: K. P. Jayaswal Research Institute.

Ñanamoli, T.(Ed.). (2010). Abhidharmakośabhāşya [The Discourse on the Not-self Characteristic]. Retrieved from http://www.accesstoinsight.org/tipitaka/sn /sn22/sn22.059.nymo.html

Balasubramanian R. (1992). Advaita Vedānta on the Problem of Enworlded Subjectivity. In D. P. Chattopadyaya, L. Embree, \& J. Mohanty (Eds.), Phenomenology and Indian Philosophy (77-93). New York: SUNY Press.

Balslev, A.N. (1992). Analysis of I-consciousness in the Transcendental Phenomenology and Indian Philosophy. In D. P. Chattopadyaya, L. Embree, \& J. Mohanty (Eds.), Phenomenology and Indian Philosophy (113-140). New York: SUNY Press. 
Burte, D. P. (2015). "Nature" and "Elementary Nature" in Phenomenology and Sāṅkhya. Journal of Indian Council of Philosophical Research, 32 (1), 31-43.

Goenka, S., \& Twokov, H. (2000). Superscience: An Interview with S. N. Goenka on the Techniques of Buddhist Practice. Tricycle, 10 (2). Retrieved from https://tricycle.org/magazine/superscience/

Husserl, E. (1983). Ideas Pertaining to a pure Penomenology and to a Phenomenological Philosophy. The Hague: Martinus Nijhoff.

Kochumuttom, T. (1982). A Buddhist Doctrine of Experience. Delhi: Motilal Banarsidass.

Lusthaus, D. (2002). Buddhist Phenomenology, a Philosophical Investigation of Yogācāra Buddhism and the Chieng Wei-Shih Lun. London: Routledge.

Mohanty, J. N. (1962). Reflections on the Nyāya Theory of Avayavipratyakșa. Journal of Indian Academy of Philosophy, I (1), 33-41.

Narada, V.T. (1979). A Manual of Abhidhamma. Malaysia: Buddhist Missionary Society.

Narada, V.T. (1988). The Buddha and His Teachings. Malaysia: Buddhist Missionary Society.

Puligandla, R.(1970). Phenomenological Reduction and Yogic Meditation. Philosophy East and West, 20(1), 9-33

Shuhmann, K. (1992). Husserl and Indian Thought. In D. P. Chattopadyaya, L.Embree, \& J. Mohanty (Eds.), Phenomenology and Indian Philosophy (20-43). New York: SUNY Press.

Sinari, R. (1970). The Method of Phenomenological Reduction and Yoga. Philosophy East and West, 15(3-4), 217-228.

Tarski, A. (1944). The Semantic Conception of Truth and the Foundation of Semantics. Philosophy and Phenomenological Research, 4(3), 341-376.

Vignemont, F. de. (2015). Bodily Awareness. Stanford Encyclopaedia of Philosophy. Stanford Encyclopedia of Philosophy Archive. Retrieved from https://plato.stanford.edu/archives/spr2018/entries/bodily-awareness/

Wittgenstein, L.(1922). Tractatus Logico-philosophicus. London: Kegan Paul, Trench Trubner \& Co. Ltd. 